\title{
EFFECT OF COW AGE AND STOCKING RATE ON MILK OUTPUT AND MILKING DURATION
}

\author{
Department of Cattle Breeding, National Research Institute of Animal Production, Kraków, Poland \\ ${ }^{1}$ The Dobrzyniewo Stud Ltd., Poland
}

\begin{abstract}
The study was performed with Polish Holstein-Friesian (PHF) cows maintained in changing environmental conditions. Two groups of animals were established (with and without an outside yard), which were subjected to temporary crowding. The effects of age and rate of change in stocking density on milk output and milking duration were also determined. It was found in the study that cow age is a variable highly differentiating the cows in milk yield and milk quality parameters. The change in housing conditions (crowding) reduced milk yield by $8.92 \mathrm{~kg}$ in the section without outdoor access and by $7.46 \mathrm{~kg}$ in the section with outdoor access. In both experimental groups, milking time decreased with decreasing milk production. Outdoor access alleviated the adverse effects of increased stocking density and reduced stress.
\end{abstract}

Key words: milking time/ animal welfare/ dairy cows.

\section{INTRODUCTION}

In Poland, milking time and thus milking speed are considered a functional trait which has been extensively studied to include it in the national merit index. As reported by Januś et al. (2004), in both multiparous and primiparous cows, milking speed increases with increasing milk yield. A study with Astronaut milking robots showed that average milking duration fluctuated around 5 minutes, but took 8 minutes in $8.6 \%$ and 10 minutes in $2.7 \%$ of the cows (Olechowicz et al. 2006). In a study with Simmental cows (Januś and Borkowska 2013), milking duration, which averaged $7.22 \mathrm{~min}$, increased significantly with each successive calving and decreased with advancing lactation. At the same time, the time of day had no effect on milking duration. A study by Choroszy et al. (2010) with Simmental cows showed milking speed to change with lactation stage, from $1.27 \mathrm{~kg}$ on day 300 to $1.48 \mathrm{~kg} / \mathrm{min}$ on day 100. This suggests that selection for shorter milking duration can be carried out also in older cows, because high correlations are observed between successive lactations. Thus, selection for traits that define milking duration is justified in view of the new milking technology and improved milking function. The aim of the study was to determine the effect of age and milk production level of dairy cows maintained in changing welfare conditions on the duration of their milking.

Corresponding author: Piotr Wójcik, Department of Cattle Breeding, National Research Institute of Animal Production, Krakowska 1, 32-083 Balice, Poland, e-mail: piotr.wojcik@izoo.krakow.pl, ORCID: 0000$-0002-3873-2739$ 


\section{MATERIAL AND METHODS}

The study was conducted at the Experimental Station of the National Research Institute of Animal Production in Chorzelów (Podkarpackie voivodship) with a group of Polish Holstein-Friesian cows of black-and-white variety (PHF). Average milk production on the farm ranged from $10908 \mathrm{~kg}$ milk in the group of primiparous cows (64 head) to $11844 \mathrm{~kg}$ milk in the group of third lactation cows (15 head), with an average foundation herd size of 240 lactating cows. During the study period, two groups of experimental animals (25 cows each) were established (Table 1). Groups I and II were formed by the analogue method in terms of the number of cows in a specific lactation:

- group I - 25 cows housed in sections without outdoor access and subjected to temporary crowding - initial area $3.80 \mathrm{~m}^{2} /$ animal.

- group II - 25 cows housed in sections with outdoor access and subjected to temporary crowding - initial area $7.74 \mathrm{~m}^{2} /$ animal.

In different experimental periods, stocking density changed according to the scheme shown below.

Table 1. Changes in stocking density and living area in different study groups depending on experimental period

\begin{tabular}{lcccc}
\hline \multirow{2}{*}{ Experimental period } & \multicolumn{5}{c}{ Group } \\
\cline { 2 - 5 } & & $\mathrm{I}$ & $\mathrm{m}$ & $\mathrm{II}$ \\
\cline { 2 - 5 } & head & $\mathrm{m}^{2} / \mathrm{head}$ & $\mathrm{head}$ & $\mathrm{m}^{2} / \mathrm{head}^{-}$ \\
\hline Comparative period A & 25 & 3.80 & 25 & 7.74 \\
Experimental period B & 30 & 3.16 & 30 & 6.45 \\
Experimental period C & 35 & 2.71 & 35 & 5.35 \\
\hline
\end{tabular}

Animals in different experimental groups were kept in free stalls. Daily milking was performed in a herringbone milking parlour and the cows were fed the same TMR diets. Daily production data for groups I and II were derived from the AFIFARM dairy herd management system, modules Afilab and Afiact. The Afilab system was installed in the milk parlour and analysed data for milk yield per milking session, estimates of fat, protein and lactose content, fat-to-protein ratio, conversion content of FCM (Fat Corrected Milk) $(\mathrm{kg})=0.4 \times($ milk yield, $\mathrm{kg})+15 \times($ fat yield, $\mathrm{kg})$ and ECM (Energy Corrected Milk) $(\mathrm{kg})=$ [milk yield, $\mathrm{kg} \times(0.38$ $\times($ fat content, \%) $+0.24 \times($ protein content, \%) $+0.17 \times($ lactose content, \%)] / 3.14, milking duration and milk conductivity per 24 hours.

All the animals participated in the A4 milk recording scheme carried out by the Polish Federation of Cattle Breeders and Dairy Farmers and were analysed for milk yield on test day, content of fat, protein and lactose, and somatic cell count. These parameters were determined at the Federation's laboratory.

The milking duration of the studied cows was examined based on the data collected in three periods:

A - comparative period,

$B$ - experimental period,

C - experimental period. 
The results were statistically analysed using SAS software based on the studied parameters and factors affecting the results obtained. Because the groups differed in the number of animals, LSM procedure of SAS 9.3 was used in the statistical analyses. The following model was used in statistical analysis of the measurements:

$$
Y_{i j k l m}=\mu+a_{i}+b_{j}+c_{k}+d_{l}+e_{i j k l m}
$$

where:

$\mathrm{Y}_{\mathrm{ijk} / \mathrm{m}}$ - analysed trait,

$\mu$ - overall mean,

$a_{i}-$ effect of factor (calving number I-VI),

$b_{j}$ - effect of factor (group I-II),

$c_{k}-$ effect of factor (study period I-II),

$d_{l}-$ effect of factor (cow's sire),

$e_{i j k l m}$ - random error.

\section{RESULTS AND DISCUSSION}

Group I, housed at standard number in the section without outdoor access (Table 2), was characterized by high average daily milk yield of the cows $(26-36 \mathrm{~kg})$ except for the fourth lactation, in which cows yielded $19.29 \mathrm{~kg}$ milk on average (differences at $P \leq 0.01$ ). The predominance of protein content over fat content in the first, second and third lactation ( $P \leq 0.01$ ) was confirmed by the predominance of ECM over FCM. This was caused by the high milk yield of the cows in a given lactation, and also by the greater fluctuations in milk fat compared to milk protein content. Pilarska (2014), who investigated the milk yield of cows in 2007-2009, showed protein content to vary from $3.14 \%$ to $3.74 \%$ and fat content from $3.85 \%$ to $4.51 \%$. In the fifth lactation, in which the highest milk yield was obtained $(36.08 \mathrm{~kg}), \mathrm{FCM}$ was higher than ECM. In the analysed lactations, electrical conductivity did not exceed 11 mmho. Milking duration varied between 6.45 and $7.91 \mathrm{~min}$ and depended on the level of milk production. It was longest for the milk production level of $36.08 \mathrm{~kg}$. This milking duration could also be affected by the age of animals, because a study by Wójcik and Olszewski (2015) showed that younger animals had higher stress levels than older cows. In the present study, primiparous cows were characterized by one of the longest milking durations with milk production level of $35.10 \mathrm{~kg}$ and highest ECM (40.30).

Table 2. Milking duration and milk parameters in experimental group I in different lactations in comparative period $(A)$ based on Afifarm data

\begin{tabular}{|c|c|c|c|c|c|}
\hline $\begin{array}{l}\text { Number of } \\
\text { lactation }\end{array}$ & $\begin{array}{c}\text { Milking duration } \\
{[\mathrm{min}]} \\
\bar{x} / \mathrm{sd}\end{array}$ & $\begin{array}{c}\text { Milk yield } \\
{[\mathrm{kg}]} \\
\bar{x} / \mathrm{sd}\end{array}$ & $\begin{array}{c}\mathrm{FCM} \\
{[\mathrm{kg}]} \\
\bar{x} / \mathrm{sd} \\
\end{array}$ & $\begin{array}{c}\text { ECM } \\
{[\mathrm{kg}]} \\
\bar{x} / \mathrm{sd}\end{array}$ & $\begin{array}{c}\text { Conductivity of } \\
\text { milk [mmho] } \\
\bar{x} / \mathrm{sd}\end{array}$ \\
\hline 1 & $7.18^{\mathrm{ABCa}}$ & $35.10^{A B}$ & $30.70^{\mathrm{A}}$ & $40.30^{\mathrm{AB}}$ & $9.74^{\mathrm{ABC}}$ \\
\hline$n=651$ & 1.47 & 7.30 & 6.42 & 8.74 & 1.01 \\
\hline II & $6.86^{\mathrm{AC}}$ & $33.23^{\mathrm{Aa}}$ & $29.48^{\mathrm{A}}$ & $38.50^{\mathrm{AB}}$ & $10.57^{\mathrm{A}}$ \\
\hline$n=1416$ & 1.51 & 8.14 & 7.05 & 9.13 & 1.04 \\
\hline III & $6.65^{A D}$ & $27.34^{\mathrm{CB}}$ & $23.76^{\mathrm{A}}$ & $30.51^{\mathrm{A}}$ & $10.94^{\mathrm{AD}}$ \\
\hline$n=865$ & 1.51 & 10.29 & 8.38 & 10.28 & 1.21 \\
\hline IV & $6.45^{\mathrm{B}}$ & $19.29^{\mathrm{A}}$ & $18.54^{\mathrm{A}}$ & $30.83^{\mathrm{B}}$ & $10.54^{\mathrm{BD}}$ \\
\hline $\mathrm{n}=117$ & 1.21 & 9.66 & 8.39 & 9.83 & 0.82 \\
\hline $\mathrm{V}$ & $7.91^{\mathrm{CDa}}$ & $36.08^{\mathrm{BCda}}$ & $33.78^{\mathrm{A}}$ & $28.06^{\mathrm{A}}$ & $10.35^{\mathrm{Ce}}$ \\
\hline $\mathrm{n}=101$ & 1.53 & 15.42 & 14.27 & 16.08 & 1.55 \\
\hline
\end{tabular}

Within column for $\mathrm{AA}-\mathrm{P} \leq 0.01$; aa $-\mathrm{P} \leq 0.05$. 
Group II was formed by cows housed at standard number in the section with outdoor access (Table 3 ). It was characterized by high average daily milk yield in different lactations (1 to 5) ranging from $22.10 \mathrm{~kg}$ to $39.38 \mathrm{~kg}$, and, similar to group I, fifth lactation cows produced most milk. Differences between the groups were statistically significant. The normal milk conductivity values were evidence of no mastitis-related problems. The difference in milking time between fifth lactation cows $(8.48 \mathrm{~min}$ ) and primiparous cows $(6.43 \mathrm{~min}$ ) was around 2 minutes, although these values showed a milk yield difference of around 4.86 I $(P \leq 0.01)$. Although, like in group I, milk yield was highest in the fifth lactation, FCM had no advantage over ECM.

Table 3. General characteristics of milk yield traits in experimental group II in different lactations in comparative period $(\mathrm{A})$ based on Afifarm data

\begin{tabular}{|c|c|c|c|c|c|}
\hline $\begin{array}{l}\text { Number of } \\
\text { lactation }\end{array}$ & $\begin{array}{c}\text { Milking duration } \\
\text { [min] } \\
\bar{x} / \mathrm{sd}\end{array}$ & $\begin{array}{l}\text { Milk yield } \\
\quad[\mathrm{kg}] \\
\bar{x} / \mathrm{sd}\end{array}$ & $\begin{array}{l}\text { FCM } \\
{[\mathrm{kg}]} \\
\bar{x} / \mathrm{sd}\end{array}$ & $\begin{array}{l}\text { ECM } \\
{[\mathrm{kg}]} \\
\bar{x} / \mathrm{sd}\end{array}$ & $\begin{array}{c}\text { Conductivity of } \\
\text { milk [mmho] } \\
\bar{x} / \mathrm{sd}\end{array}$ \\
\hline 1 & $6.43^{\mathrm{AB}}$ & $34.52^{\mathrm{AB}}$ & $29.78^{\mathrm{AB}}$ & $39.60^{\mathrm{A}}$ & $9.67^{\mathrm{Aa}}$ \\
\hline $\mathrm{n}=849$ & 1.17 & 6.98 & 5.37 & 8.06 & 0.67 \\
\hline II & $6.92^{\mathrm{Aa}}$ & $38.91^{\mathrm{A}}$ & $33.07^{\mathrm{B}}$ & $45.24^{\mathrm{AB}}$ & $10.29^{\mathrm{AB}}$ \\
\hline $\mathrm{n}=974$ & 1.55 & 9.61 & 8.79 & 11.09 & 0.75 \\
\hline III & $7.26^{\mathrm{A}}$ & $32.46^{\mathrm{A}}$ & $28.58^{\mathrm{AB}}$ & $38.92^{\mathrm{BC}}$ & $10.13^{\mathrm{AB}}$ \\
\hline $\mathrm{n}=1051$ & 1.52 & 11.89 & 9.34 & 12.86 & 0.77 \\
\hline IV & $7.20^{\mathrm{BCa}}$ & $22.10^{\mathrm{A}}$ & $18.45^{\mathrm{AB}}$ & $25.32^{\mathrm{AC}}$ & $11.14^{\mathrm{AB}}$ \\
\hline $\mathrm{n}=304$ & 1.64 & 10.54 & 7.52 & 10.78 & 0.84 \\
\hline $\mathrm{V}$ & $8.48^{\mathrm{AC}}$ & $39.38^{\mathrm{B}}$ & $33.00^{\mathrm{A}}$ & $42.55^{\mathrm{AC}}$ & $9.81^{\mathrm{Ba}}$ \\
\hline$n=141$ & $\begin{array}{l}0.40 \\
1.06\end{array}$ & 8.82 & 7.41 & 10.54 & 0.45 \\
\hline
\end{tabular}

Within column for $\mathrm{AA}-\mathrm{P} \leq 0.01$; aa $-\mathrm{P} \leq 0.05$.

In group I, the change in housing conditions (crowding) had an effect on production results (Table 4). Milk yield exhibited a considerable decline $(P \leq 0.01)$. Electrical conductivity remained at a similar level. Milk duration was shortened with decreasing milk yield $(P \leq 0.01)$. During the experimental period $\mathrm{B}$, fat-corrected milk (FCM) decreased between lactations, with highly significant differences. Distinct changes were noted in period $C$, when FCM decreased from $28.5 \mathrm{~kg}$ to $24.5 \mathrm{~kg}$. The short-term change in housing conditions in this group with a concurrent lack of outdoor access had an effect on the production parameters. Daily milk production considerably declined $(8.92 \mathrm{~kg})$ in experimental period $\mathrm{C}$, when crowding was twice as high as in period $B(P \leq 0.01)$. At the same time, FCM milk yield increased by 1.12 $\mathrm{kg}$ and $3.5 \%$ FCM production by $0.99 \mathrm{~kg}$. Wang et al. (2016) reported the milk yield to increase from $31.91 \mathrm{~kg}$ to $33.11 \mathrm{~kg}$ when stocking density increased from 100 to $129 \%$.

Table 4. Characteristics of milk yield traits in experimental group I in different study periods

\begin{tabular}{|c|c|c|c|c|c|}
\hline Study period & $\begin{array}{c}\text { Milking duration } \\
\text { [min] } \\
\bar{x} / \mathrm{sd}\end{array}$ & $\begin{array}{l}\text { Milk yield } \\
{[\mathrm{kg}]} \\
\bar{x} / \mathrm{sd}\end{array}$ & $\begin{array}{l}\text { FCM } \\
{[\mathrm{kg}]} \\
\bar{x} / \mathrm{sd}\end{array}$ & $\begin{array}{l}\text { ECM } \\
{[\mathrm{kg}]} \\
\bar{x} / \mathrm{sd}\end{array}$ & $\begin{array}{c}\text { Conductivity of } \\
\text { milk [mmho] } \\
\bar{x} / \mathrm{sd}\end{array}$ \\
\hline $\begin{array}{c}\text { Comparative A } \\
n=2221\end{array}$ & $\begin{array}{l}6.91^{\mathrm{A}} \\
1.49\end{array}$ & $\begin{array}{c}32.10^{\mathrm{AB}} \\
9.10\end{array}$ & $\begin{array}{c}28.58^{\mathrm{A}} \\
8.43\end{array}$ & $\begin{array}{l}36.80^{\mathrm{A}} \\
10.27\end{array}$ & $\begin{array}{r}10.41 \\
1.20\end{array}$ \\
\hline $\begin{array}{c}\text { Experimental B } \\
n=790\end{array}$ & $\begin{array}{l}6.83^{\mathrm{B}} \\
1.43 \\
\end{array}$ & $\begin{array}{c}32.28^{\mathrm{B}} \\
7.87\end{array}$ & $\begin{array}{c}28.27^{\mathrm{B}} \\
0.00\end{array}$ & $\begin{array}{c}37.24^{\mathrm{B}} \\
9.05^{2}\end{array}$ & $\begin{array}{r}10.44 \\
1.03\end{array}$ \\
\hline $\begin{array}{c}\text { Experimental C } \\
n=282\end{array}$ & $\begin{array}{l}6.55^{\mathrm{AB}} \\
1.62\end{array}$ & $\begin{array}{c}23.18^{\mathrm{A}} \\
9.19\end{array}$ & $\begin{array}{l}24.58^{\mathrm{AB}} \\
8.07\end{array}$ & $\begin{array}{l}28.13^{\mathrm{AB}} \\
10.61\end{array}$ & $\begin{array}{r}10.43 \\
1.40\end{array}$ \\
\hline
\end{tabular}

Within column for $A A-P \leq 0.01$; aa $-P \leq 0.05$. 
In group II, which had outdoor access, production parameters changed with changing housing conditions (Table 5). Milk yield also decreased $(P \leq 0.01)$, but to a lesser extent than in group I. In the first experimental period $(B)$ cows produced the most milk $(35.96 \mathrm{~kg})$ and at the same time the least fat $(P \leq 0.01)$. This period was also most favourable in terms of FCM and ECM. The observed decline in daily milk production during the experimental period $\mathrm{C}$, by $7.46 \mathrm{~kg}$ in relation to the comparative period $A(P \leq 0.01)$ and by $8.91 \mathrm{~kg}$ in relation to period $B(P \leq 0.01)$, was unquestionably due to overstocking. However, the milk production level in this group (II) was higher in both experimental periods than in group I, which may result from the fact that the cows were allowed outdoor access. Therefore, although milking duration decreased in the study periods $(P \leq 0.01)$ in connection with the milk production level, when compared to group I it was longer by 0.07 to $0.15 \mathrm{~min}$. Thus, the additional living area was a strong stress-reducing factor. Falk et al. (2012), who investigated cattle behaviour under freestall conditions with pasture access, found that when humidity and thermal conditions were unfavourable, cows preferred to stay outdoors at night and to remain in the barn during the day even if it was crowded. Such behaviour may, in a sense, explain why, despite having outdoor access, cows experience stress associated with overstocking, which results, among others, in a milk yield decline. In group II, conductivity of milk was also observed to decrease with increasing stocking density.

Table 5. Characteristics of milk yield traits in experimental group II in different study periods

\begin{tabular}{|c|c|c|c|c|c|}
\hline Study period & $\begin{array}{l}\text { Milking duration } \\
\text { [min] } \\
\bar{x} / \mathrm{sd}\end{array}$ & $\begin{array}{l}\text { Milk yield } \\
{[\mathrm{kg}]} \\
\bar{x} / \mathrm{sd}\end{array}$ & $\begin{array}{l}\mathrm{FCM} \\
{[\mathrm{kg}]} \\
\bar{x} / \mathrm{sd}\end{array}$ & $\begin{array}{l}\text { ECM } \\
{[\mathrm{kg}]} \\
\bar{x} / \mathrm{sd}\end{array}$ & $\begin{array}{l}\text { Conductivity of } \\
\text { milk [mmho] } \\
\bar{x} / \mathrm{sd}\end{array}$ \\
\hline Comparative A & $6.98^{\mathrm{A}}$ & $34.51^{\mathrm{A}}$ & $29.66^{A}$ & $40.12^{\mathrm{A}}$ & $10.08^{a}$ \\
\hline $\mathrm{n}=2214$ & 1.50 & 11.16 & 9.19 & 12.51 & 0.84 \\
\hline $\begin{array}{c}\text { Experimental B } \\
n=815\end{array}$ & $\begin{array}{l}6.98^{\mathrm{B}} \\
1.44\end{array}$ & $\begin{array}{c}35.96^{\mathrm{A}} \\
9.77\end{array}$ & $\begin{array}{c}30.53^{\mathrm{A}} \\
8.41\end{array}$ & $\begin{array}{l}41.39^{A} \\
11.18\end{array}$ & $\begin{array}{c}10.11^{\mathrm{b}} \\
0.70\end{array}$ \\
\hline $\begin{array}{c}\text { Experimental C } \\
n=288\end{array}$ & $\begin{array}{l}6.62^{\mathrm{AB}} \\
1.56\end{array}$ & $\begin{array}{c}27.05^{\mathrm{A}} \\
9.53\end{array}$ & $\begin{array}{c}24.58^{\mathrm{A}} \\
7.71\end{array}$ & $\begin{array}{l}33.56^{\mathrm{A}} \\
10.90\end{array}$ & $\begin{array}{l}9.64^{\mathrm{ab}} \\
0.70\end{array}$ \\
\hline
\end{tabular}

Within column for $\mathrm{AA}-\mathrm{P} \leq 0.01$; aa $-\mathrm{P} \leq 0.05$.

\section{CONCLUSION}

It was found in the study that cow age is a variable highly differentiating the cows in milk yield and milk quality parameters. The short-term change in housing conditions by increasing stocking density from $3.8 \mathrm{~m}^{2} /$ head to $3.16 \mathrm{~m}^{2} /$ head without outdoor access resulted in low milk yield losses. Further crowding (up to $2.71 \mathrm{~m}^{2} / \mathrm{head}$ ) caused the milk yield to decrease by $8.92 \mathrm{~kg}$. The cows with permanent outdoor access, subjected to a short-term increase in stocking density from $7.74 \mathrm{~m}^{2} /$ head to $6.45 \mathrm{~m}^{2} /$ head did not decrease their daily milk production, but ECM and FCM declined. When stocking density was increased to $5.35 \mathrm{~m}^{2} / \mathrm{cow}$, milk production declined by $7.46 \mathrm{~kg}$. With increased stocking density, milking time was found to decrease with decreasing milk production, while outdoor access alleviated the adverse effects of unfavourable housing conditions. Although milking duration decreased in the study periods $(P \leq 0.01)$ in connection with the milk production level, when compared to the group without outdoor access, it was longer by 0.07 to $0.15 \mathrm{~min}$. 


\section{REFERENCES}

Choroszy B., Choroszy Z., Łopieńska M., Korzonek H. 2010. Szybkość oddawania mleka u krów rasy simentalskiej w zależności od kolejnej laktacji i jej stadium [Milking speed in Simmental cows according to lactation numer and stage of lactation]. Rocz. Nauk. Zoot. 37(2), 115-122. [in Polish]

Falk A.C., Weary D.M., Winckler C., von Keyserlingk M.A.G. 2012. Preference for pasture versus freestall housing by dairy cattle when stall availability indoors is reduced. J. Dairy Sci. 95, 6409-6415.

Januś E., Bąk M., Strzelecki W. 2004. Zależność pomiędzy dobową wydajnością krów a szybkością oddawania mleka [The relationship between the cow's daily productivity and the speed of flow milk]. Prz. Hod. 2, 1-2. [in Polish]

Januś E. Borkowska D. 2013. Parametry doju krów rasy montbeliarde [The parameters of Montbeliarde cows milking]. J. Centr. Eur. Agr. 14(1), 134-142. [in Polish]

Olechowicz J., Lipiński M., Jaśkowski J.M. 2006. Główne problemy robotyzacji doju krów [Main issues in robotic milking of cows]. Med. Weter. 62(6), 611-616. [in Polish]

Pilarska M. 2014. Wpływ pory roku i kolejnej laktacji na wydajność krów i parametry fizjologiczne mleka [Effect of season of the year and numer of lactation on performance of cows and physicochemical parameters of their milk]. Wiad. Zootech. 52(2), 3-12. [in Polish]

Wang F.X., Shao D. F., Li S. L., Wang Y. J., Azarfar A., Cao Z. J. 2016. Effects of stocking density on behavior, productivity, and comfort indices of lactating dairy cows. J. Dairy Sci. 99, 3709-3717.

Wójcik P., Olszewski A. 2015. Use of pedometers to analyse 24-hour activity and fertility of limousin cows. Folia Pomer. Univ. Technol. Stetin., Agric. Aliment. Pisc., Zootech. 322(36)4, 119-124.

\section{WPŁYW WIEKU I STOPNIA ZAGĘSZCZENIA KRÓW NA WIELKOŚĆ PRODUKCJI I CZAS DOJU}

Streszczenie. Badania prowadzono na krowach rasy PHF utrzymywanych $w$ zmiennych warunkach środowiskowych. Utworzono dwie grupy zwierząt (z okólnikiem oraz bez niego), które podlegały okresowemu zwiększeniu obsady na $1 \mathrm{~m}^{2}$. Określono wpływ wieku oraz stopnia zmiany obsady na poziom produkcji oraz czas doju krów. Stwierdzono, że wiek krów jest czynnikiem bardzo różnicującym krowy pod względem wydajności mleka oraz jego parametrów jakościowych. Zmiana warunków utrzymania krów poprzez zwiększenie stopnia obsady powoduje straty w wydajności mleka na poziomie $8,92 \mathrm{~kg}$ w sektorze bez okólnika oraz o 7,46 kg w sektorze z okólnikiem. Pomimo wzrostu stopnia obsady obecność okólnika zdecydowanie łagodzi niekorzystne warunki dla dobrostanu.

Słowa kluczowe: czas doju, dobrostan, bydło mleczne. 